\title{
PRINCIPLE OF NON-DISCRIMINATION AND EQUAL TREATMENT
}

\author{
Anca Moroșteș* \\ "Vasile Goldiş" Western University of Arad, Romania,_E-mail: anca_moro@yahoo.com \\ Narcisa Mihaela Stoicu \\ "Vasile Goldiş" Western University of Arad, Romania, E-mail: stoicu.narcisa@gmail.com
}

(Received: October 2021; Accepted: November 2021; Published: December 2021)

\begin{abstract}
With its evolution, society has introduced human rights as intrinsic values in its acts on the regulation of relations of human nature. Significant victories in the struggle for social freedoms materialized with the adoption of the first declarations of rights, which formed the basis for the passing of later constitutions. Therefore, the modern state, inclined to the protection of its citizens, is unthinkable in its functionality, without stating and guaranteeing human rights in their fundamental law. In addition, it is necessary to point out that these rights have a universal character, namely their protection for each person, regardless of nationality, ethnicity, race, religion, level of health, person's status, etc. The Constitution of Romania states in art. 15 par. (1) on this that: "All citizens benefit from the rights and freedoms enshrined in the Constitution and other laws and have the obligations provided for therein".
\end{abstract}

Keywords: citizen: law; equality; treatment; non-discrimination.

\section{Introduction}

Starting from the constitutional regulation in the fundamental law and although it does not form the object of the present work, a fundamental principle of law is that to which each right a correlative obligation corresponds.

Therefore, the protection of the fundamental rights of the individual constitutes, first of all, an obligation of the State through its law-making and coercion mechanisms, but also a correlative obligation of individuals arising from the right of each individual who has the correlative obligation to act or not in such a way as not to harm the right enjoyed by the person next to him.

\footnotetext{
* Corresponding author: Anca Moroşteş. E-mail: anca_moro@yahoo.com
}

Copyright (C) 2021 The Author(s). Published by VGWU Press

This is an Open Access article distributed under the terms of the Creative Commons BY 4.0 license (Creative Commons - Attribution 4.0 International - CC BY 4.0) which permits unrestricted use, distribution, and reproduction in any medium, provided the original author and source are credited. 
Moroșteș, A., Stoicu, N.M., (2021)

Principle of Non-Discrimination and Equal Treatment

As such, through its law-making role, the state intervenes in a society based on democratic principles by adopting those norms of social cohabitation, which protect its citizens from those actions or inactions meant to harm the rights they enjoy off. Even more, we could say that this protection offered by the state also refers to potential "attacks" on human rights, coming precisely from the state, respectively from its institutions, at the central or territorial level. In this context of harm by the state of some person's rights, we point out the provisions of art. 52 par. (1), (2) and (3) of the Constitution of Romania which provides that: "the person aggrieved in a right of his own or in a legitimate interest, by a public authority, by an administrative act or by the failure to settle within the legal term of an application, is entitled to obtain the recognition of the claimed right or legitimate interest, the annulment of the act and the compensation of the damage. The terms and limits for exercising this right shall be established by an organic law. The State is liable for damages caused by judicial errors. The liability of the state is established according to the law and does not remove the liability of the magistrates who exercised their office in bad faith or gross negligence."

Through the constitutional regulation of this constitutional principle, Romanian citizens without distinction of race, nationality, ethnic origin, language, religion, gender, opinion or political affiliation, wealth or social origin, may make equal use of all the rights provided for in the Constitution and laws, they may participate equally in the political, economic, social and cultural life, without privileges and discrimination, they are treated equally both by public authorities and by citizens. Equal rights are regulated in Article 16 par. and in Article 4 par. (2) of the Constitution of Romania, which provides that: "Citizens are equal before the law and public authorities, without privileges and without discrimination. No one is above the law", and "Romania is the common and indivisible homeland of all its citizens, without distinction of race, nationality, ethnic origin, language, religion, gender, opinion, political affiliation, wealth or social origin."

The text regulated in Art. 6 par. (2), which states that: „no one is above the law" was introduced by the Constituent Assembly, in the idea of strengthening the principle of equal rights as a natural echo of the Charter of Paris (1990) provisions relative to the rule of law.

According to art. 16 of the Romanian Constitution, equality in law is a general principle of the law found in all the legal fields. It is also set out as a principle in the Charter of Fundamental Rights of the European Union, in Article 20. This principle is expressed both legally and doctrinally and according to the case law. Over time, equality has crystallized both as a principle of law and as a fundamental right and as a legal category. This is how it is that on an evolutionary scale, it has gone from inequality to equality and even more to the so-called discrimination, positive or 
Moroşteş, A., Stoicu, N.M., (2021)

"right to difference", as a means of protecting certain disadvantaged categories. Equality is a complex constitutional principle that is defined both by reporting to difference and by reporting to discrimination. Equality does not mean uniformity, because, as such, people are not equal by nature [1].

\section{National and international approaches to the principle of non-discrimination and equal treatment}

The depth and complexity of the principle of equality, as well as its vast scope of application, has led to the identification in the case-law of the Constitutional Court of Romania of a "right of difference", as an expression of the equality of citizens before the law, incompatible with uniformity [2].

The constitutional provisions aimed at equal rights between citizens refer to the recognition in their favor of fundamental rights and freedoms, not to the identity of legal treatment over the application of measures, regardless of their nature. Thus, it is justified not only the admissibility of a different legal regime from certain categories of persons but also its necessity. It would be contrary to the provisions contained in art. Article 16 par. (1) of the Constitution to claim uniformity where there are clear and objective differences in the situation, or, as the case may be, of the applicable legal regime. Infringement of the principle of equality and nondiscrimination implies that a difference of treatment is applied to equal cases, without there being any objective and reasonable reasoning, or the existence of a disproportion between the aim pursued by the unequal treatment and the employed means.

The law must be used to give equal chances to all citizens. This is the purpose of the constitutional provision that citizens are equal towards the law and public authorities, without any favors and discriminations. The fact that no one is above law shows us that the intention of the lawmakers is to create a rule of law in which the law is the one that governs and not the individuals 'free will. Only the law can be equal for all. The will of each individual expresses the needs each person has, depending on the situation in which each person finds himself or lives in.

First of all, equality means first of giving opportunities to all citizens. The constitutional principle of equal rights presupposes the identity of solutions only for identical situations, this principle not opposing to ruling different solutions for people in distinct situations [3].

Secondly, equality means non-discrimination. In this way, article 16 of the Romanian Constitution must be interpreted and applied in accordance with art. 4 par. (2) of the Constitution according to which, "Romania is the common and indivisible homeland of all its citizens, regardless of race, nationality, ethnic origin, language, religion, gender, opinion, political affiliation, wealth or social origin. These criteria of non-discrimination also provided for in Article 21 of the Charter of Fundamental

204 S sciendo Journal of Legal Studies Volume 28 Issue 42/2021 
Moroșteș, A., Stoicu, N.M., (2021)

Rights of the European Union form the basis for the application of the principle of equality. The relation between Article 16 and Article 4 is not a relation from the general rule to the particular rule but is rather a coordination relationship between the two rules by which they supplement each other. While Article 16 establishes the principle of legality, Article 4 establishes the criteria for achieving this nationality. Equality can mean, on the one hand, equality of performance, for example, any employee is entitled to a wage or equal work, men and women have the same salary, but also relative equality, considering the situation in which a person finds itself, for example, the right to a decent level, which is a right with different content for each individual.

Strictly formal equality can be called non-discrimination. Etymologically, nondiscrimination means the prohibition of distinguishing between objects, of establishing a separation between them, a differentiation from their distinctive features. Discrimination means any distinction, exclusion, limitation, or preference based on race, nationality, ethnic origin, language, gender, opinion, political affiliation, wealth, or social origin.

We are in the presence of a breach of the "principle of equality and nondiscrimination when a difference of treatment is applied to equal cases, without there being an objective and reasonable reasoning or if there is a disproportion between the aim pursued by the unequal treatment and the means used" [4].

Therefore, "the difference of treatment must seek or have the effect of restricting or removing the recognition, use or exercise, on an equal basis, of human rights and fundamental freedoms or of the rights recognised by law, in the political, economic, social and cultural fields or in any other areas of public life" [5].

Both the national lawmaker and the Community lawmakers have defined the concept of discrimination as representing the different treatment applicable to persons in a comparable situation. To discriminate is to make a difference or distinction, to distinguish, to reject, to apply arbitrary or unequal treatment unduly between two persons or situations in comparable positions. Differences, restrictions, exclusions, or preferences related to an individual's characteristics are discriminatory if their purpose or effect is to diminish or exclude rights, opportunities, or freedoms. Discrimination is not only an action or behavior but also the intention to promote social inequalities, it is a form of marginalization.

Gender equality is a policy of the European Union with an old tradition, having its origins in the provisions of the Treaty of 1957. Article 141 established for the first time the principle of equality between the genders, as regards remuneration, and various other provisions dealing with the issue of equal treatment were added to the Treaty. 
Moroşteş, A., Stoicu, N.M., (2021)

The European Parliament has played an important role in supporting policies for the unity of opportunities, especially through its Commission for Women's Rights and Gender Legality (FEMM). In the area of treatment on the labor market, Parliament passed, based on the ordinary legislative procedure, the (EU) Directive 2019/1158 of June 20,2019, on the balance between the professional and private life of parents and carers through which it was abolished and Directive 2010/18/EU, and the recent proposal for a directive on the improvement of the application of the principle of equal pay for the same work or work of same value between men and women through the salary transparence and enforcement [6] mechanisms (COM(2021)0093) [7].

At the same time, the European Parliament has contributed to the general development of policies in the light of gender law through its own reports, workshops, and hearings, and by drawing the attention of other institutions to certain issues, in which sense they passed a report with the title "Promoting gender-based legality in education and careers in the fields of science, technology, engineering and mathematics (STIM)" in April 2021. The European Parliament also discussed the report with the title "Equality between Women and Men in the European Union during 2018-2020" and a public hearing with the title "Increasing EU support for women entrepreneurs and investing women, including through the MFF 20212027", was also organized. The FEMM Committee also organized a workshop on 'The role of education in the prevention of violence against women".

In the course of 2021, the European Parliament organized an online seminar with the title "International Women's Day - Women at the Forefront Fight against COVID19", which focused on scientific and care activities. The work carried out, within the framework of the European Parliament, in the area of gender legality, continued by organizing a parliamentary meeting, at the level of committees with the title, "We are powerful: women in the Forefront Fight against COVID-19", which took place on March 4, 2020, with the participation of personalities such as us Vice-President Kamala Harris and Prime Minister of New Zeeland, Jacinda Ardern, at the Parliament plenary session that was organized on the occasion of the International Women's Day on March 8, 2021.

The European Parliament promotes and applies the integration of gender issues into the work of all its committees. To this end, two gender networks have been set up, which are coordinated by the Commission for women's rights. The network of presidents and vice-presidents for gender integration brings together deputies in the European Parliament who support the introduction of a gender perspective in the work of their committees. They are assisted by a network of administrators in charge of gender mainstreaming, in the secretariat of each commission. The high-level group on gender equality promotes training and better awareness of gender integration among the Staff of the Parliament and the policy groups. 
Moroşteş, A., Stoicu, N.M., (2021)

Principle of Non-Discrimination and Equal Treatment

An intensive activity on gender equality policies is also found in the European Commission which adopted on March 5, 2020, the 2020-2025 Gender Equality Strategy. This strategy involves an ambitious framework for the next few years on how to promote gender equality in Europe and beyond. The strategy is based on a vision of a Europe in which women and men, girls, and boys, in all their diversity, are protected from violence and stereotypes and have the possibility to prosper and to hold leadership positions.

The first steps of the strategy passed by the European Commission concerned the proposed acquisition of binding measures to ensure salary transparency. In this respect, the Commission presented a proposal for a directive on how to strengthen the implementation of the principle of equal pay for the same work or for work of the same value between men and women through salary transparence and enforcement mechanisms. In March 2021, the Commission adopted an action plan for the implementation of the European Pillar of Social Rights, which has gender equality in the center, and which sets ambitious targets for women's participation in the labor market and for ensuring the education and care of preschool children, among others. Adequate minimum wages can also help to reduce the difference in pay between women and men, as more women than men are paid the minimum wage. To this end, in October 2020, the Commission presented a proposal for an EU Directive to make sure that EU workers are protected by guaranteeing appropriate minimum salaries [8].

The European Commission is currently working on a new legislative initiative to fight against gender-based violence, and public consultation on this initiative was launched in February 2021. In parallel, the accession of the European Union to the Istanbul Convention of the Council of Europe remains a high priority for the Commission. In 2020, the Commission adopted the first-in-history European Union strategy on the victims' rights, intensifying its focus on gender violence.

In our country, this principle is clearly visible in all fields of activity, protecting the equal rights of all citizens, to the detriment of the equality of collective persons, legal entities.

\section{a) Equal rights for women and men}

Equal rights for women and men concern the equal exercise of all rights, equality in the occupation of public offices and dignities, equal work, equal pay, etc. It starts from the reality that women represent a large part of the country's population, their work being incorporated into all material or spiritual accomplishments.

According to the Romanian legislation, "equal opportunities between men and women" represents "to consider the capacities, the men's, respectively the women's different aspirations and needs, and the equal treatment of them". 
Moroșteş, A., Stoicu, N.M., (2021)

The Romanian State, through the competent authorities, has to adopt measures to promote equal opportunities and treatment between women and men, to implement policies and programs that lead to the guarantee of equal opportunities and treatment between women and men, and to eliminate all forms of discrimination based on gender, in all the areas of public life in Romania. In this respect, the law regulates the prohibition of any forms of discrimination that allow employers to use practices that could lead to a disadvantage of people of a certain gender, in connection with employment relations.

The same prohibition is provided for as regards the women's and men's access to all levels of vocational education and training, including an apprenticeship at the workplace, to further training and, in general, to lifelong education, educational establishments of all levels, social factors involved in instructive-educational processes, as well as all other providers of training and development services, authorized according to the law, being obliged to include in the national education programs topics and activities related to equal opportunities and treatment between women and men.

Equal opportunities between women men and men are also regulated in terms of participation in decision-making, meaning that civil and military institutions and central and local public authorities, economic and social units, as well as political parties, employers and trade unions and other non-profit entities, have to promote and support balanced participation of women and men in leadership and decisionmaking and to take all necessary measures to ensure the balanced participation of women and men in leadership and decision-making [9].

However, if we look at the Romanian Parliament, we see that only $11.81 \%$ of its members are women. As of September 1, 2015, of the 383 deputies, only 53 were women, and out of the 167 senators, only 12 were women. And in other key decisionmaking positions in important state institutions, women hold places - out of 22 ministers, only 4 are women, and out of 9 judges of the Constitutional Court, only 2 are women.

One of the most serious forms of inequality in Romania affects women who, due to the lack of a functional social protection system, are forced to take care of and support the older or younger members of the family. This situation makes difficult their social and professional life, restricts their freedoms and their opportunities, and predisposes them to depression, loneliness, and low self-esteem, according to international studies. For example, a recent European study of 514 million people shows that many married women and housewives have difficulty balancing their careers with family life. Many women in Romania are in charge alone of household chores and of the household, as well as with the growth of children, while a male person is in the most many ways "exempted" from these responsibilities. The same 
Moroșteș, A., Stoicu, N.M., (2021)

Principle of Non-Discrimination and Equal Treatment

happens in terms of caring for older people, a responsibility that falls under the care of women, due to the lack of a system of nursing for elderly people.

The COVID-19 pandemic has amplified gender-based violence against women, confirming the results of studies carried out over several years, which show that the risk of domestic violence is increasing in times of crisis. Confinement measures were taken to keep people safe at home. However, the home has proved not to be a safe place for everyone, and the lockdown measures have played an obvious role in the significant increase in the reported domestic violence.

b) Equality of rights without distinction of race, nationality or ethnic origin, language, wealth, or social origin.

In each state, to a greater or lesser extent, populations with different ethnic features are grouped together, which has led to the growing assertion in international law of the need for states to observe the rights of national minorities. The objective and subjective elements that characterize the notion of minority constitute the premises of the State's obligation, especially with regard to persons belonging to national minorities, to respect and guarantee their right to identity. In this respect, the state has both a negative obligation to abstain, that is, not to harm, through the adopted measures, the identity of persons belonging to national minorities, and a positive one, to support the preservation and development of their identity as part of the universal cultural heritage. The Constitution of Romania provides in this respect that the Romanian state recognizes and guarantees to persons belonging to national minorities the right to preserve, develop and express ethnic, cultural, language and religious identities [10].

This principle starts from the reality that people of other nationalities, called national minorities, such as Roma, Hungarians, Germans, Jews, Turks, Serbs, Armenians, etc., have also settled on the territory of Romania. They are all citizens of Romania and must enjoy, equally, all the rights enshrined in the constitution, according to the provisions contained in art. Art. 4 par. 2 and in art. 6 of the Constitution of Romania. Relevant in this respect are the provisions contained in Article 4 par. (2) of the Romanian Constitution which states that "Romania is the common and indivisible homeland of all its citizens, without distinction of race, nationality, ethnic origin, language, religion, gender, opinion, political affiliation, wealth or social origin". and the provisions contained in article 6 according to which "the State recognizes and guarantees to persons belonging to national minorities the right to preserve, develop and express their ethnic, cultural, linguistic and religious identity. The protection measures taken by the state for the preservation, development and expression of the identity of persons belonging to national minorities must be compliant with the principles of equality and non-discrimination in relation to other Romanian citizens." 
Moroşteş, A., Stoicu, N.M., (2021)

c) Equality of rights without distinction of religion actually complements the other two aspects by regulating that the political or religious choices of citizens are not speculated in the sense of discrimination.

Discrimination based on religion or belief can be based on any religion, belief, or similar philosophical thinking, hence the lack of any religious belief, such as atheism. For example, art. 139 of the Labor Code stipulated the obligation for employers to grant days off for "Good Friday - the last Friday before Easter, the first and second day of Easter, the first and second day of Pentecost" for employees belonging to a legal religious cult, Christian, depending on the date on which they are celebrated by that cult. For persons who belong to other legal religious cults, other than Christian days, days off are granted by the employer on days other than public holidays established according to the law or annual leave. The employer's choice of denying granting the two days off for each of the two annual religious holidays declared as such by the legal religious cults, other than Christian religious denominations, to the persons belonging to them, represents an act of discrimination. Discrimination on the grounds of religion in matters of employment and employment relations retains its illegality even when it is a sect prohibited on the ground that it violates the law, poses a danger to public order, national security, public health or morals, or decent behaviors, since it must be disjointed between violations of the legal limits of freedom of conscience and the principle of equal treatment which is violated as long as the effect provided for by law, regardless of the discriminatory criterion used, occurs: the non-granting, restriction or removal of the recognition, use or exercise of the rights provided for in the labor legislation. The exceptions are jobs for which belonging to a particular religion is a genuine and determining professional requirement, such as, for example, teachers of religion or priests.

\section{Conclusions}

Although religious beliefs cannot constitute a legal basis for dismissal, the French Constitutional Court has admitted, by way of derogation from this rule, that employees who have been employed to perform a certain task involving a community of thought and faith with the employer may be sanctioned with the termination of the labor agreement if they do not fulfill these obligations. Employees may not invoke a religious belief or religion as a reason for refusing to perform their obligation to perform work or other obligations imposed by law or by the individual labor contract.

We align ourselves with the opinions according to which equality is a complex constitutional principle, which is not defined only in relation to the opposite notion of discrimination, but also "in relation to the complementary notion of difference, which it comes to encompass in fact. From this perspective, equality is no longer synonymous with uniformity, but rather approaches proportionality. The diversity of 
Moroşteş, A., Stoicu, N.M., (2021)

concrete situations must be reflected in the legal norm that must adapt to different circumstances [11]."

In conclusion, equality of rights for the citizens is the constitutional principle according to which the Romanian citizens, regardless of their race, nationality, ethnic origin, language, religion, gender, opinion or political party, wealth or social affiliation, can make use of equally all the rights provided for in the Constitution and by the law for participating in the political, economic, social and cultural life, without privileges or discrimination, they are treated equally both by the public authorities and by the other citizens. This principle is consecrated by art. 16 par. (1) and (3), as well as by art. 4 par. (2) of the Constitution.

The equality of rights of citizens concerns all the rights which the Romanian citizens have, without distinction from the fact that they are entered in the text of the Constitution or other normative acts. At the same time, equality of rights manifests itself in all areas of activity. The rule resulting from international regulations should also be retained, according to which the no measure taken in the event of public danger, which threatens the existence of the country, cannot lead to discrimination based on race, religion, color, gender, language, or social origin. The law provides for the equal protection of all citizens and sanctions discrimination.

\section{Acknowledgments}

The authors thank the anonymous reviewers and editor for their valuable contribution.

\section{Funding}

This research received no specific grant from any funding agency in the public, commercial, or non-profit sectors.

\section{Author Contributions}

The authors contributed equally to this article.

\section{Disclosure Statement}

The authors have not any competing financial, professional, or personal interests from other parties. 
Moroșteş, A., Stoicu, N.M., (2021)

\section{References}

1. Enache M., Deaconu Ş., (2019). Drepturile şi libertăţile fundamentale în jurisprudenţa Curţii Constituţionale (Fundamental Rights and Freedoms in the Case-law of the Constitutional Court), Vol. I, Ch. Beck Publishing House, Bucharest, 2019, p. 3.

2. Muraru, I., Tănăsescu, E.S., (2019). Constitutia României. Comentariu pe articole (Constitution of Romania. Comment on articles), C.H. Beck Publishing House, Bucharest.

3. Stoicu, M.N., (2021). Drept constitutional și instituții politice (Constitutional Law and Political Institutions), vol. I, Casa Cărţii de Ştiinţă Publishing House, Cluj-Napoca.

4. Tănăsescu, E.S., (1999). Principiul egalităţii în dreptul românesc (The principle of equality in the Romanian Law), All Beck Publishing House, Bucharest.

5. ****, Law no. 202 of April 19, on the legality of opportunities and treatment for women and men, published in the Official Journal Romania no. 326 of 5 June 2013.

\section{Notes:}

[1] Enache, M., Deaconu, Ș. (2019). Drepturile şi libertăţile fundamentale în jurisprudenţa Curţii Constituţionale (Fundamental Rights and Freedoms in the Case-law of the Constitutional Court), Vol. I., Ch. Beck Publishing House, Bucharest, p. 3.

[2] See, to that effect, Muraru, I., Tănăsescu, E.S., (2008). Constitutia României. Comentariu pe articole (Constitution of Romania. Comment on articles), C.H. Beck Publishing House, Bucharest, p. 151.

[3] H.C.C.J., Decision nr. 1710/2011 of March 23, 2011.

[4] Decision no.148/2001 on Exception of unconstitutionality of the provisions of Art. 8 par. (3) of Decree-Law No. 118/1990 on granting of rights to persons persecuted for political reasons by the dictatorship established with effect from 6 March 1945, as well as for those deported abroad or constituted as prisoners, republished, with subsequent amendments; Decision no. 685/2012 on the exception of unconstitutionality of the provisions of Art. 7 par. (2) the final thesis of Annex No. VI - Occupational Family of Budgetary Functions "Justice" at Framework Law no. 284/2010 in the unitary remuneration of staff paid from public funds. [5] H.C.C.J., Decision No. 4147/2011 of September 16, 2011.

[6] (EU) Directive 2019/1158 must be implemented by the EU Member States before 1 August 2021.

[7] Committees FEMM and EMPL are discussing this proposal for a directive right now.

[8] The proposal is now being debated in Parliament's FEMM and EMPL committees.

[9] Law No. 202 of 19 April, on equal opportunities and treatment between women and men, published in Official Journal of Romania no. 326 of 5 June 2013.

[10] To see, in this respect, Stoicu, M.N., (2021). Drept constituțional și instituții politice (Constitutional law and political institutions) vol. I, Casa Cărţii de Ştiinţă Publishing House, Cluj-Napoca, p. 98.

[11] To see, in this regard, Tănăsescu, E.S., (1999). Principiul egalităţii în dreptul românesc (Principle of equality in Romanian law), All Beck Publishing House, Bucharest, p. 34. 